\title{
Sources and fate of organic carbon and nitrogen from land to ocean: Identified by coupling stable isotopes with $\mathrm{C} / \mathrm{N}$ ratio
}

\author{
Yuan Li ${ }^{a}, 1$, Haibo Zhang ${ }^{\mathrm{a}, 1}$, Chen $\mathrm{Tu}^{\mathrm{a}}$, Chuancheng Fu ${ }^{\mathrm{a}}$, Yong Xue ${ }^{\mathrm{b}}$, Yongming Luo ${ }^{\mathrm{a}}$ * \\ ${ }^{a}$ Key Laboratory of Coastal Environmental Processes and Ecological Remediation, Yantai Institute of Coastal Zone Research, Chinese Academy of Sciences, \\ Yantai 264003, PR China \\ ${ }^{\mathrm{b}}$ College of Environmental and Chemical Engineering, Shanghai University, Shanghai 200444, PR China
}

\section{A R T I C L E I N F O}

\section{Article history:}

Received 1 January 2016

Received in revised form

17 August 2016

Accepted 23 August 2016

Available online 24 August 2016

\section{Keywords:}

Organic carbon

Nitrogen

Sediment source

Stable isotopes

Yellow River coastal plain

Bohai sea

\begin{abstract}
A B S T R A C T
The transport of organic matter in coastal areas plays an important role in global biogeochemical cycles. The present study used stable isotopes including carbon $\left(\delta^{13} \mathrm{C}\right)$ and nitrogen $\left(\delta^{15} \mathrm{~N}\right)$ and $\mathrm{C} / \mathrm{N}$ ratio to assess the sources and fate of organic carbon and nitrogen in soils and sediments of a coastal plain-river plumebay system. Changes of the $\delta^{13} \mathrm{C}$ and $\delta^{15} \mathrm{~N}$ values from natural to agricultural soils in the Yellow River coastal plain reflected the contribution of $\mathrm{C}_{4}$ carbon, decomposition of organic matter and application of nitrogen fertilizer. The organic carbon in the marine sediments adjacent to the coastal plain mainly originated from $\mathrm{C}_{3}$-dominated terrestrial systems. The spatial heterogeneity of both $\delta^{13} \mathrm{C}$ and $\delta^{15} \mathrm{~N}$ values indicated that Yellow River sediment transport and anthropogenic wastewater discharge were two driving forces for the sedimentary organic carbon and nitrogen dynamics in large river plume and inner bay areas. Meanwhile, the marine primary production and denitrification process as affected by excessive nutrient input also contributed to the cycling of organic matter. Wetland soils, cropland soils, vegetable soils, coastal and deep-sea sediments were the five systems controlling the cycle of organic carbon and nitrogen in the study area. A significant positive correlation between $\delta^{13} \mathrm{C}$ and $\delta^{15} \mathrm{~N}$ in the Yellow River coastal plain-plume-bay region was observed, which implied the flux of organic matter from a labile pool in source regions into a more recalcitrant pool in sink regions. These findings would provide a better understanding of carbon sequestration in the coastal soil and sediment.
\end{abstract}

(C) 2016 Elsevier Ltd. All rights reserved.

\section{Introduction}

The coastal zone and river mouth systems are important interfaces between the continent and ocean, and the exchange and sequestration of the carbon and nitrogen among land, river and ocean have an impact on the biogeochemistry of these elements at a global scale (Hedges and Keil, 1995; de Haas et al., 2002; Bianchi and Allison, 2009). The carbon and nitrogen accumulated in the coastal sediments are heterogeneous and complex mixture of organic materials with different characteristics and from different sources (marine and freshwater phytoplankton, soil, leaf debris, wastewater, kerogen etc.) (Cloern et al., 2002; Lamb et al., 2006; Schreiner et al., 2013; Cai et al., 2015). Soils from different land

\footnotetext{
* Corresponding author. Address: Yantai Institute of Coastal Zone Research, Chinese Academy of Sciences, Yantai 264003, PR China.

E-mail address: ymluo@yic.ac.cn (Y. Luo).

1 Yuan Li and Haibo Zhang contributed equally to this work.
}

types are the main source of riverine organic matter, contributing $>90 \%$ of the buried organic carbon in the marine sediments occurring in "terrigenous-deltaic" regions near river mouths (Berner, 1989; Raymond and Bauer, 2001; Tao et al., 2015). Land-use change including reclamation and managed agro-ecosystem development can increase export of soil-derived organic carbon stored in aquatic sediments (Bianchi, 2011). The delivery, reaction, and burial of organic carbon and nitrogen are dependent on transport-reaction cycles within both the terrestrial sources and oceanic sedimentary sinks (Blair and Aller, 2012). Understanding the sources, characteristics and environmental fate of the organic matter in the coastal soils and sediments is key to understanding the importance of the coastal system on the mitigation of climate change (Bauer et al., 2013; Regnier et al., 2013).

Due to the complex nature of carbon and nitrogen in the coastal zone, stable isotope $\left(\delta^{13} \mathrm{C}\right.$ and $\left.\delta^{15} \mathrm{~N}\right)$ techniques and $\mathrm{C} / \mathrm{N}$ ratio are robust tools that have been frequently used to elucidate sources, mixing and transformations of carbon and nitrogen in the terrestrial, estuarine and coastal regions, based on the different 
signatures of the sources (Zhang et al., 2007; Ramaswamy et al., 2008; Cai et al., 2015). In general, terrestrial organic matter has depleted $\delta^{13} \mathrm{C}$ and $\delta^{15} \mathrm{~N}$ values when compared to marine organic matter (Lamb et al., 2006). However, a single stable isotope is insufficient to identify the sources of organic matter because of the complicated contributions in the coastal areas. Hence, dual isotopes (both $\delta^{13} \mathrm{C}$ and $\delta^{15} \mathrm{~N}$ ) along with the carbon and nitrogen ratios can be applied to improve the accuracy of source identification (Middelburg and Herman, 2007; Cai et al., 2015). Moreover, geographical mapping of isotope ratios over a large area can also contribute to identifying the specific sources in different regions by using the spatial variability of the isotopic signatures (Hu et al., 2006; Liu et al., 2015). Furthermore, $\delta^{13} \mathrm{C}$ and $\delta^{15} \mathrm{~N}$ are also useful in understanding the fate of organic matter in the coastal environment based on the isotopic fractionations caused by physical, chemical, and biological processes. For example, the organic matter degradation driven by bacterial and/or fungal activities results in the enrichment of isotopic values due to the preferential decomposition of ${ }^{13} \mathrm{C} /{ }^{15} \mathrm{~N}$ depleted compounds (Lehmann et al., 2002). Middelburg and Herman (2007) observed an increase in $\delta^{15} \mathrm{~N}$ values up to $20 \%$ driven by heterotrophic activities in the Scheldt estuary.

The Yellow River coastal plain is a newly formed coastal fluvial plain since 1855 . In total, 12 major shifts of the river course occurred between 1855 and 1976 due to rapid channel siltation (Pang and Si, 1979). In 1996, the main channel was artificially diverted northeast forming the Qing 8 course. Due to the large sediment load $\left(1 \times 10^{9}\right.$ t year $^{-1}$ in history) of the Yellow River, the river mouth area expanded rapidly at a mean speed of $42 \mathrm{~km}^{2}$ year $^{-1}$ before 1970s (Zhang et al., 1990), while it decreased to $20-25 \mathrm{~km}^{2}$ year $^{-1}$ from 1976 to 1999 (Wang and Liang, 2000). Although the sediment load continued to decline, partly due to dam constructions and soil and water conversion measures, the coastal area nevertheless increased from 2003 to 2011 (Kong et al., 2015). Meanwhile, the coastal erosion of promontory occurred when the water and sediment supply became cut off (Kong et al., 2015). The Yellow River coastal plain is thus an active land-ocean interaction area, and the river mouth region is heavily impacted by sediment input from a substantial amount of terrestrial materials, including particulate organic matter from the Yellow River sediment discharge (Qiao et al., 2010; Tao et al., 2015). Since the discovery of the Shengli oilfield in 1960s, the Yellow River Delta region has undergone rapid industrialization. In 1983, Dongying City as the core area of the delta was founded to meet the economic and social development. Recently, the Yellow River coastal plain has become as an ecological agricultural and industrial production area at the national level promoted by China's state council since 2009. The rapid urbanization and economic growth could result in the inputs of agricultural wastes, industrial discharge and city sewage wastewater into the ocean through the Yellow River and other large rivers around the Bohai Bay and Laizhou Bay (Zhang et al., 2006). All these discharges eventually contribute to the organic matter in the sediments of the Bohai Sea.

Although some studies have been carried out to assess the contribution of terrigenous organic matter to the Yellow River plume and its immediate surrounding areas (Bigot et al., 1989; Cai, 1994), a detailed understanding of the sources and fate of carbon and nitrogen from the coastal plain and rivers to the bulk sediment in offshore marine areas remains poorly documented. Data on organic carbon, total nitrogen and their elemental ratios and isotope ratios $\left(\delta^{13} \mathrm{C}\right.$ and $\left.\delta^{15} \mathrm{~N}\right)$ covering both soil and sediment across the coastal plain, river plume and bay area were collected. The objectives of the study based on these data include (1) seeking the patterns of organic matter in the soils from nature to cropping systems, (2) elucidating the sources of carbon and nitrogen deposited in the marine sediment, and (3) examining the fate of the terrigenous organic matter in the coastal zone.

\section{Materials and methods}

\subsection{Study area}

The study area is on the north coast of China, covering the Yellow River coastal plain, the Yellow River plume, Laizhou Bay and south of Bohai Bay from the land to the sea (Fig. 1). The area is characterized of a huge amount of sediment loading in the coastal zone. Approximately $1 \times 10^{9}$ t year $^{-1}$ sediment form Yellow River is discharged into the Bohai Sea, which is the second largest sediment input from a single river worldwide (Milliman and Syvitski, 1992), with $85 \%$ of the annual total sediment input during the flood season (Li et al., 1998).

The suspended sediments in the Yellow River plume are transported southward and southeastward to Laizhou Bay, and northward to Bohai Bay (Qiao et al., 2010). The transportation of the suspended sediments along the coast is dominated by isobathparallel tidal current with a velocity of $<1.0 \mathrm{~m} / \mathrm{s}$, which flows
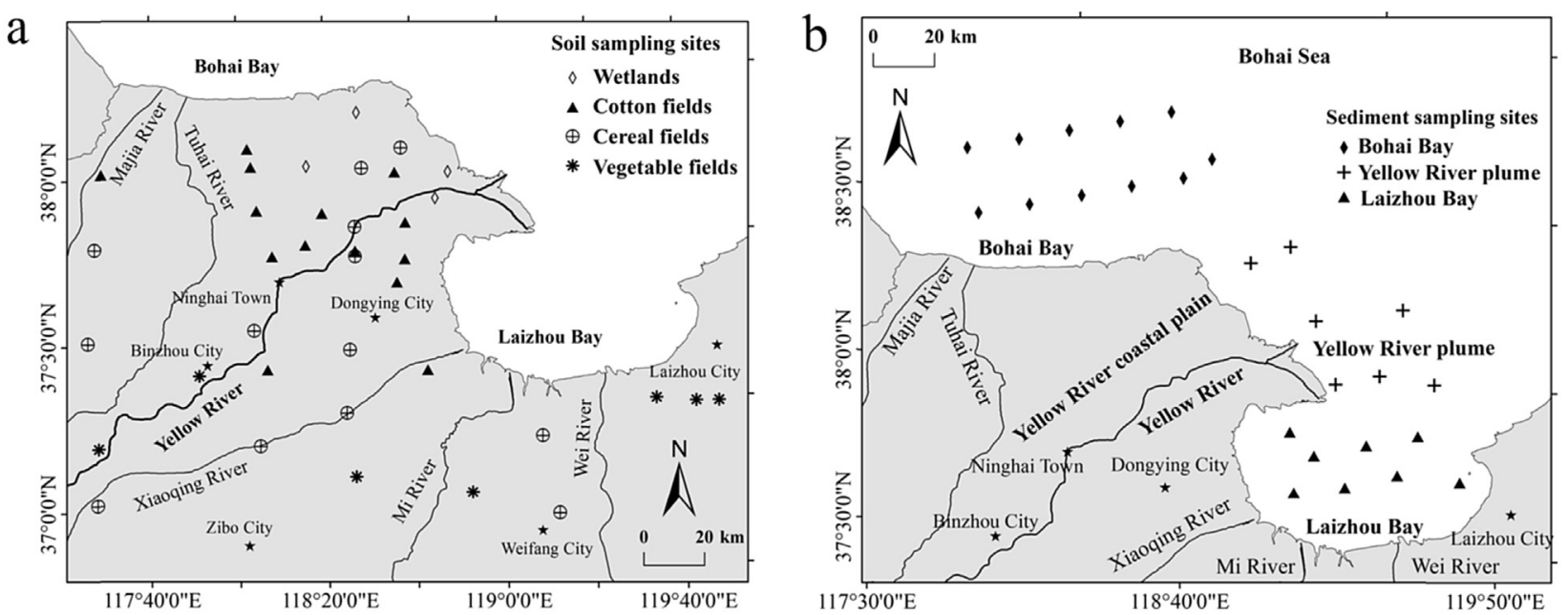

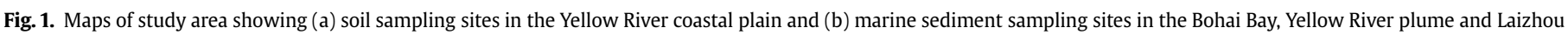
Bay. The maps were generated using ArcGIS 10.0 (ESRI, Redlands, CA, USA). 
southward during flood tide and northward during ebb tide (Qiao et al., 2010; Zang, 1996). The water depth off the Yellow River mouth is generally less than $15 \mathrm{~m}$. The tide regime is dominated by irregular semidiurnal tides with a tidal range of $<1.5 \mathrm{~m}$. Waves are closely associated with prevailing winds with a maximum velocity of $>11 \mathrm{~m} / \mathrm{s}$ (Zang, 1996). Southward winds prevail in summer and northward winds dominate in winter. The digital elevation model (DEM) map of the Yellow River Delta and the bathymetry of the Bohai Sea are shown in Fig. S1 in the supporting information.

There are 13 other rivers located in the study area from the Xuanhui River to the Wang River (Wang et al., 2015), and 5 of these are shown in Fig. 1. Most of the rivers flow through large cites and receive the input of wastewater discharge. For example, the Xiaoqing River receives wastewater from the cities of Jinan and the Zibo, Shandong Province; the Mi River flows through the largest greenhouse vegetable production base near Zibo City; the Wei River flows through the largest manufacturing base of brominated flame retardants in China located in Weifang City (Covaci et al., 2011; Wang et al., 2015).

The Yellow River coastal plain is formed by heavy sediment deposition controlled by the Yellow River and has a fan shape resulting from a swing of the frequent distributary shifts. There are three major types of landforms seaward in the coastal plain including terrace, floodplain, and coastal zone (Zhang et al., 2011). The main soil types are classified as Calcaric Fluvisols, Salic Fluvisols and Gleyic Solonchaks (Fang et al., 2005). Salt-tolerant plants including Suaeda, reed and tamarix are widely distributed in the wetland and undeveloped lands. Agriculture has developed based on the soil salinity, usually cultivated sequentially with the crops of cotton, maize, wheat and vegetable as soil salinity declines. The coastal plain is within the warm-temperate zone, with an average annual temperature of $11.7-12.6{ }^{\circ} \mathrm{C}$. The average annual precipitation ranges from 530 to $630 \mathrm{~mm}$, of which $70 \%$ occurs as rainfall during summer (May-July) (Zhang et al., 2011).

\subsection{Sample collection}

\subsubsection{Soil sampling}

Thirty-eight surface soil samples $(0-10 \mathrm{~cm})$ were collected from thirty-eight sites across the coastal plain in November 2012 (Fig. 1a). Approximately $1 \mathrm{~kg}$ samples were taken and mixed randomly from three points in a sampling space of $10 \mathrm{~m} \times 10 \mathrm{~m}$ of each site. All the soil sampling sites were classified into four groups: wetland, cotton, cereal and vegetable based on the dominant vegetation type. The vegetation in the sampling sites is dominated by $\mathrm{C}_{3}$ plants, such as suaeda (Suaeda salsa), reed (Phragmites australis) and tamarix (Tamarix ramosissima) in the wetland as well as cotton (Anemone vitifolia Buch), wheat (Triticum aestivum) and soybean (Glycine max) in the farmland. Maize (Zea mays) is the only $\mathrm{C}_{4}$ plants in the farmland.

\subsubsection{Marine sediment sampling}

A total of twenty-six surface $(0-20 \mathrm{~cm})$ marine sediment samples were collected by using a stainless steel grab sampler in August 2014. The suspended sediments transported by the Yellow River are main sources of the marine surface sediments in the studied marine areas (Qiao et al., 2010). The average sedimentation rates in the Yellow River estuary are $0.5 \mathrm{~cm} / \mathrm{yr}$ and $5.7 \mathrm{~cm} / \mathrm{yr}$ basing on the ${ }^{210} \mathrm{~Pb}$ dating and paleosol time marker methods, respectively (Da et al., 2014; Ye et al., 2015). The sedimentation rate can assure that the surface $20 \mathrm{~cm}$ of sediment vary on multidecadal time scale, which is closely associated with the organic matter decomposition and anthropogenic influence. Among the samples, 11 of them were from the southern Bohai Bay, 7 of them were close to the Yellow River plume and 8 of them were from the Laizhou Bay (Fig. 1b). The marine sediment samples were collected at an interval distance of $20 \mathrm{~km}$. The collected samples were sealed in polyethylene tubes and stored frozen at $-20^{\circ} \mathrm{C}$ before analysis.

\subsection{Sample analysis}

All the samples were air dried, pulverized, and passed through a 2-mm sieve followed by grinding to pass through a $0.145-\mathrm{mm}$ sieve by using a hand mortar. The $2-\mathrm{mm}$ samples were used for the measurement of soil salinity and grain size while the $0.145-\mathrm{mm}$ samples were used for the determination of total organic carbon (TOC), total nitrogen (TN) and stable isotopes.

TOC and TN analyses were conducted by using $0.5 \mathrm{M} \mathrm{HCl}$ to remove inorganic carbon and subsequently rinsing with deionized water to neutralize and freeze dry. The carbonate-free samples were then analyzed for the content of TOC and TN on a Vario MACRO cube elemental analyzer. Replicate analysis of well-mixed samples indicated a precision of $<1 \%$. Precision and accuracy of carbon and nitrogen content determinations were assessed through the analysis of reference material GSS-1 and GSS-4, showing a precision of $<5 \%$.

The grain size distribution of samples was measured using a Malvern Mastersizer 2000 instrument after removing organic matter and carbonates with $15 \% \mathrm{H}_{2} \mathrm{O}_{2}$ and $4 \mathrm{M} \mathrm{HCl}$ (Qiao et al., 2010). The particle sizes were less than $2 \mu \mathrm{m}$ for clay, $2-200 \mu \mathrm{m}$ for silt and 200-2000 $\mu \mathrm{m}$ for sand.

Stable isotopic analysis was performed on the carbonate-free samples ( $0.5 \mathrm{M} \mathrm{HCl} \mathrm{leaching)} \mathrm{using} \mathrm{a} \mathrm{Thermo} \mathrm{MAT253} \mathrm{mass} \mathrm{spec-}$ trometer (continuous flow mode). The results were expressed as per thousand $(\%)$ calculated as follows:

$\delta(\% 0)=\left(R_{\text {sample }} / R_{\text {standard }}-1\right) \times 1000$

where $\delta(\% 0)$ stands for $\delta^{13} \mathrm{C}(\% \circ)$ or $\delta^{15} \mathrm{~N}(\% \mathrm{o})$, and $R_{\text {sample }}$ and $R_{\text {standard }}$ are the isotopic ratios of the sample and standard, respectively. The carbon standard is Peedee Belemnite (PDB) and the nitrogen standard is atmospheric $\mathrm{N}_{2}$. All samples were analyzed twice. Reproducibility was better than $\pm 0.1 \%$ of absolute difference for both $\delta^{13} \mathrm{C}$ and $\delta^{15} \mathrm{~N}$.

\subsection{The stable isotope mass balance model}

The fractions of $\mathrm{C}_{4}$ plant (maize) derived soil organic carbon (\% $\mathrm{SOC}_{4}$ ) in cereal and vegetable fields were calculated using the following stable isotopes mass balance equation (Cook et al., 2013):

$\% \mathrm{SOC}_{4}=\left(\delta_{\mathrm{s}}-\delta_{0}\right) /\left(\delta_{\mathrm{c}}-\delta_{0}\right) \times 100$

where $\delta_{\mathrm{s}}$ is the $\delta^{13} \mathrm{C}$ of the soil samples from cereal and vegetable field, $\delta_{0}$ is the $\delta^{13} \mathrm{C}$ of reference wetland soil (ranging from $-28.3 \%$ to $-26.2 \%$, with an average of $-26.8 \%$ ), and $\delta_{\mathrm{c}}$ is the $\delta^{13} \mathrm{C}$ of maize litter (ranging from $-19 \%$ o to $-9 \%$, with an average of $-14 \%$ ) (Tang et al., 2012).

\subsection{Derivation of the two end-member mixing model}

To assess the relative proportions of terrestrial organic carbon present in surface marine sediments of the study area, a simple $\delta^{13} \mathrm{C}$-based two end-member mixing model based on the model derived by Calder and Parker (1968) and Schultz and Calder (1976) was applied to this area. The equation used is as follows:

Terrestrial OC $(\%)=\left(\delta^{13} C_{\text {marine }}-\delta^{13} \mathrm{C}_{\text {org }}\right) /$

$\left(\delta^{13} C_{\text {marine }}-\delta^{13} C_{\text {terrestrial }}\right) \times 100 \%$ 
where $\delta^{13} \mathrm{C}_{\text {marine }}$ is the $\delta^{13} \mathrm{C}$ of marine end member; $\delta{ }^{13} \mathrm{C}_{\text {terrestrial }}$ is the $\delta^{13} \mathrm{C}$ of terrestrial end member; and $\delta^{13} \mathrm{C}_{\text {org }}$ is the measured $\delta^{13} \mathrm{C}$ of a given sample. The $\delta^{13} \mathrm{C}$ value of $-27 \%$ is used as terrestrial end member based on the low $\delta^{13} \mathrm{C}$ values of the sediment samples (Table 2). This value is close to that of the terrestrial $C_{3}$ plants, with typical $\delta^{13} \mathrm{C}$ values ranging from $-32 \%$ to $-21 \%$ (Lamb et al., 2006). The marine end member is taken as $-20.9 \%$ (ranging from $-21.6 \%$ to $-20.3 \%$ for marine organisms including jellyfish, Labidocera, plankton and benthos in the offshore of the coastal plain) derived from Cai (1994).

\subsection{Data analysis}

All the measured data were normal distribution after the Kolmogorov-Smirnov test. One-way ANOVA were then used for the entire data set to compare the differences among land use types or sampling locations. A Pearson correlation analysis was performed to assess the degree of correlation among the investigated variables. All statistical analyses were carried out using SPSS version 20.0 (SPSS Inc. Chicago).

\section{Results}

\subsection{Soil properties and isotopic compositions under the different land types}

Soil properties of the different land types are shown in Table 1. The soil TOC and TN tended to decrease after the conversion from wetland to cotton field, but thereafter increased gradually and finally reached the highest values in the vegetable fields under long-term cultivation. There was also an increasing trend of soil C/N ratios and clay content, although the difference was not significant among the different land types. Soil salinity declined from the wetland to the vegetable field. The variability of these soil properties is consistent with the land use change in the Yellow River coastal plain.

The $\delta^{13} \mathrm{C}$ and $\delta^{15} \mathrm{~N}$ values ranged from $-28.3 \%$ to $-24.1 \%$ and $-0.31 \%$ to $5.67 \%$, respectively, showing a clear relation with land types. The distribution of $\delta^{13} \mathrm{C}$ from the wetland to the vegetable field showed a significantly $(p<0.05)$ increasing trend (Fig. 2a). In natural environments, $\delta^{13} \mathrm{C}$ values were lowest in the wetland $\left(-26.8 \pm 1.0 \%\right.$ ) . Compared with the wetland, the $\delta^{13} \mathrm{C}$ values were significantly $(p<0.05)$ increased in the cotton field $(-26.0 \pm 0.7 \% 0)$ and the cereal field $(-25.6 \pm 0.8 \% 0)$, and reaching the highest values in the vegetable field $(-24.7 \pm 0.3 \%$ ).

The distribution patterns of $\delta^{15} \mathrm{~N}$ were shown in Fig. 2b. The $\delta^{15} \mathrm{~N}$ values were also the lowest in the wetland $(0.69 \pm 0.81 \% 0)$. Although $\delta^{15} \mathrm{~N}$ values also followed a significantly $(p<0.05)$ increasing trend from wetland to cotton field $(3.09 \pm 1.40 \%$ ), a moderately decreasing trend could be observed from cotton field to cereal field $(2.74 \pm 1.39 \%$ ) and then to vegetable field
$(2.09 \pm 0.87 \% 0)$. However, no significant differences $(p>0.05)$ of $\delta^{15} \mathrm{~N}$ values were observed in the farmland.

\subsection{Marine sediment properties and isotopic compositions}

The TOC and TN contents in the marine sediment samples ranged from 0.63 to $6.47 \mathrm{~g} \mathrm{~kg}^{-1}$ and $0.11-0.79 \mathrm{~g} \mathrm{~kg}^{-1}$, respectively (Table 2). The highest values were observed in Bohai Bay. The TOC correlated significantly with median grain size of the marine sediment $(r=-0.930, p<0.01)$, suggesting the influence of

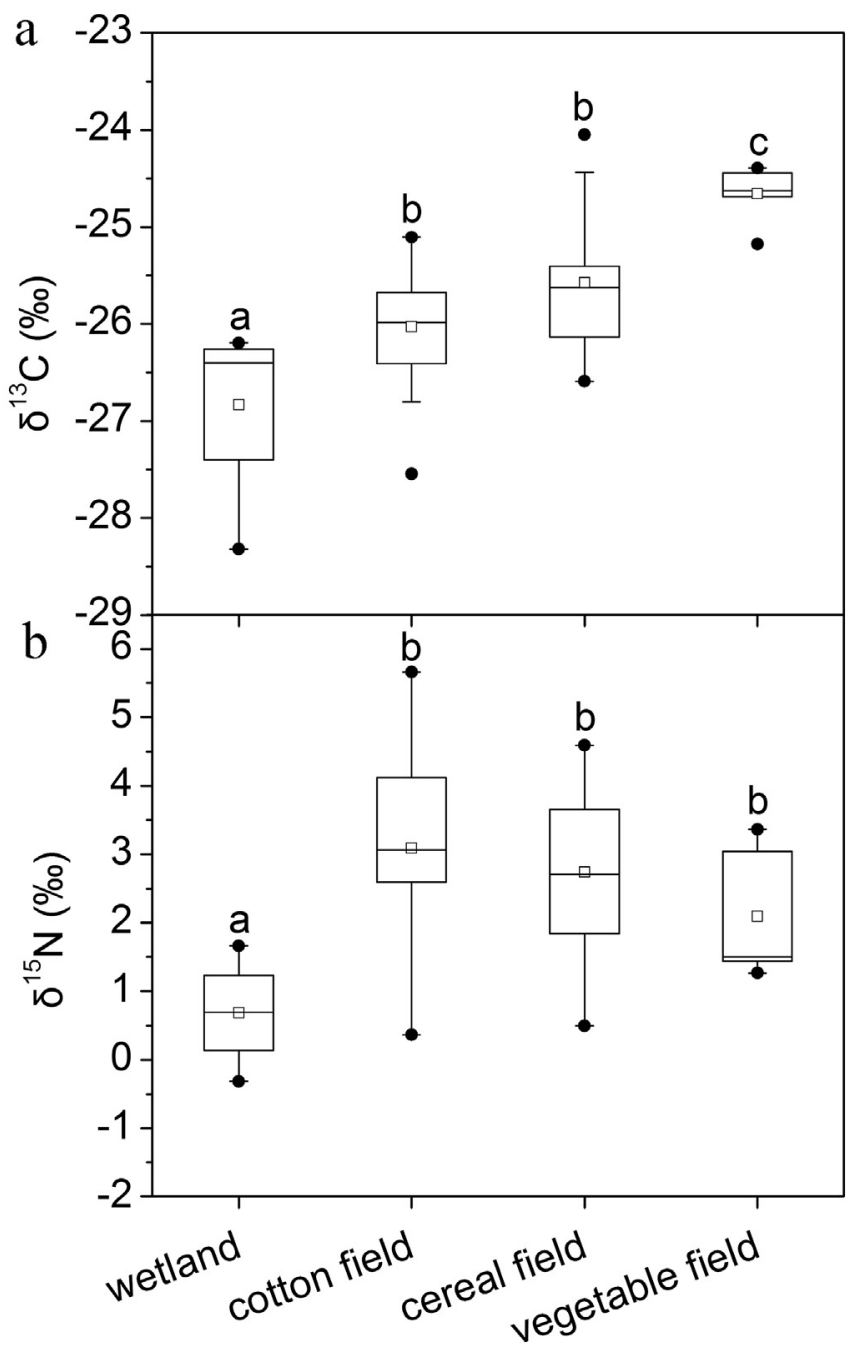

Fig. 2. Distribution patterns of (a) $\delta^{13} \mathrm{C}$ and (b) $\delta^{15} \mathrm{~N}$ under different land-use types. Values sharing the same letters are not different at $p>0.05$ (by Duncan test).

Table 1

Main properties of surface soils under different land use types in the Yellow River coastal plain.

\begin{tabular}{|c|c|c|c|c|c|c|c|c|c|c|}
\hline Land-use types & $\delta^{13} \mathrm{C}(\% 0)$ & $\delta^{15} \mathrm{~N}(\% 0)$ & $\mathrm{TN}\left(\mathrm{g} \mathrm{kg}^{-1}\right)^{\mathrm{a}}$ & TOC $\left(\mathrm{g} \mathrm{kg}^{-1}\right)^{\mathrm{b}}$ & Salinity $\left(\mathrm{g} \mathrm{kg}^{-1}\right)$ & $\mathrm{C} / \mathrm{N}^{\mathrm{c}}$ & Clay (\%) & Silt (\%) & Sand (\%) & $\% \mathrm{SOC}_{4}{ }^{\mathrm{d}}$ \\
\hline Wetland (4) & $-26.8 \pm 1.0 a$ & $0.69 \pm 0.81 a$ & $1.01 \pm 0.41 \mathrm{ab}$ & $8.53 \pm 7.08 \mathrm{ab}$ & $10.6 \pm 7.44 a b$ & $6.19 \pm 2.89 a$ & $6.17 \pm 1.81 \mathrm{a}$ & $34.0 \pm 19.0 a$ & $60.7 \pm 20.9 a$ & - \\
\hline Cotton field (14) & $-26.0 \pm 0.7 b$ & $3.09 \pm 1.40 b$ & $0.91 \pm 0.15 a$ & $5.82 \pm 1.84 a$ & $4.99 \pm 4.64 b c$ & $6.32 \pm 1.23 a$ & $6.90 \pm 1.54 a$ & $33.8 \pm 11.7 a$ & $59.3 \pm 13.2 \mathrm{a}$ & - \\
\hline Cereal field (13) & $-25.6 \pm 0.8 b$ & $2.74 \pm 1.39 b$ & $1.30 \pm 0.41 b c$ & $8.96 \pm 4.20 \mathrm{ab}$ & $1.44 \pm 1.54 c$ & $6.73 \pm 1.40 a$ & $7.15 \pm 2.10 a$ & $35.2 \pm 16.2 \mathrm{a}$ & $57.3 \pm 18.7 a$ & $9.56 \pm 5.97$ \\
\hline Vegetable field (7) & $-24.7 \pm 0.3 c$ & $2.09 \pm 0.87 b$ & $1.40 \pm 0.24 c$ & $10.5 \pm 2.5 b$ & $0.25 \pm 0.18 c$ & $7.52 \pm 1.74 a$ & $8.22 \pm 1.93 a$ & $30.2 \pm 8.0 \mathrm{a}$ & $61.6 \pm 8.4 a$ & $16.7 \pm 2.0$ \\
\hline
\end{tabular}


Table 2

Main properties of marine surface sediments.

\begin{tabular}{|c|c|c|c|c|c|c|c|c|}
\hline Station series & $\delta^{13} \mathrm{C}(\% 0)$ & $\delta^{15} \mathrm{~N}(\% 0)$ & $\mathrm{TN}\left(\mathrm{g} \mathrm{kg}^{-1}\right)^{\mathrm{a}}$ & $\mathrm{TOC}\left(\mathrm{g} \mathrm{kg}^{-1}\right)^{\mathrm{b}}$ & $\mathrm{C} / \mathrm{N}^{\mathrm{c}}$ & Clay (\%) & Silt (\%) & Sand (\%) \\
\hline Bohai Bay (11) & $-25.0 \pm 0.4 a$ & $4.61 \pm 0.48 a$ & $0.52 \pm 0.20 a$ & $4.94 \pm 1.62 \mathrm{a}$ & $9.82 \pm 1.61 \mathrm{a}$ & $11.9 \pm 3.3 a$ & $87.6 \pm 4.0 \mathrm{a}$ & $0.53 \pm 1.17 a$ \\
\hline Yellow River plume (7) & $-25.5 \pm 0.8 a$ & $3.70 \pm 0.75 b$ & $0.29 \pm 0.21 b$ & $2.72 \pm 1.56 b$ & $9.93 \pm 2.66 a$ & $8.33 \pm 4.58 \mathrm{ab}$ & $91.7 \pm 4.6 \mathrm{ab}$ & n.a. ${ }^{\mathrm{d}}$ \\
\hline Laizhou Bay $(8)^{e}$ & $-25.1 \pm 0.7 a$ & $4.63 \pm 1.14 a$ & $0.26 \pm 0.16 b$ & $2.63 \pm 1.63 b$ & $10.3 \pm 4.2 \mathrm{a}$ & $5.47 \pm 3.66 b$ & $93.8 \pm 4.0 \mathrm{~b}$ & $0.77 \pm 1.88 a$ \\
\hline Total (26) & $-25.1 \pm 0.7$ & $4.38 \pm 0.87$ & $0.4 \pm 0.2$ & $3.6 \pm 1.9$ & $9.99 \pm 2.78$ & $9.24 \pm 4.52$ & $90.3 \pm 4.78$ & $0.43 \pm 1.21$ \\
\hline
\end{tabular}

Values are mean \pm S.D. Values sharing the same letters in one column indicate no significant difference by Duncan test $(p>0.05)$.

a $\mathrm{TN}$, total nitrogen.

b TOC, total organic carbon.

c $\mathrm{C} / \mathrm{N}, \mathrm{TOC} \mathrm{g} \mathrm{kg}^{-1} / \mathrm{TN} \mathrm{g} \mathrm{kg}^{-1}$

d n.a., not available.

e Two points missed in detecting sediment texture.

hydrodynamic effects and the association with minerals on the preservation of organic matter in sediments. The TN content was correlated significantly with the TOC $(r=0.956, p<0.01)$, implying the great majority of sedimentary nitrogen was of organic origin.

The $\delta^{13} \mathrm{C}$ values of marine sediments fell to a range of $-27.1 \%$ to $-24.2 \%$, exhibiting a slight seaward decrease in the Yellow River plume (Fig. 3a). No significant $(p>0.05)$ difference of $\delta^{13} \mathrm{C}$ values was observed among Bohai Bay $(-25.0 \pm 0.4 \%$ ), Yellow River plume $(-25.5 \pm 0.8 \%)$ and Laizhou Bay $(-25.1 \pm 0.7 \% 0)$. The $\mathrm{C} / \mathrm{N}$ ratio changed from 5.87 to 19.4 (mean 9.99) (Fig. 3b), presenting a significantly negative correlation with $\delta^{13} \mathrm{C}(\mathrm{r}=-0.420, p<0.05)$.

The $\delta^{15} \mathrm{~N}$ values ranged from $2.13 \%$ to $5.91 \%$, displaying a

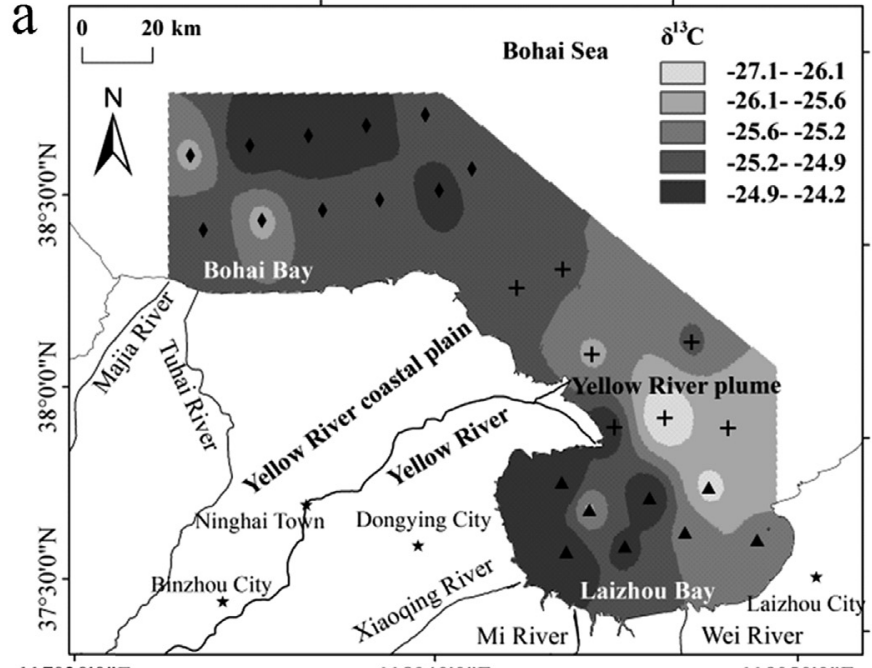

$117^{\circ} 30^{\prime} 0^{\prime \prime} \mathrm{E}$ $118^{\circ} 40^{\prime} 0^{\prime \prime} \mathrm{E}$

$119^{\circ} 50^{\prime} 0^{\prime \prime} \mathrm{E}$

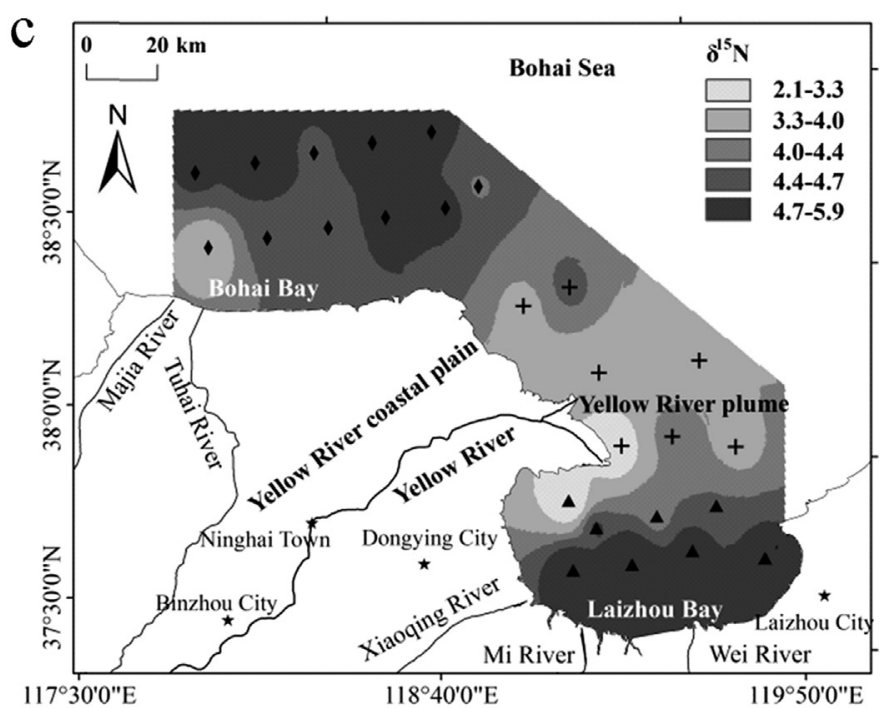

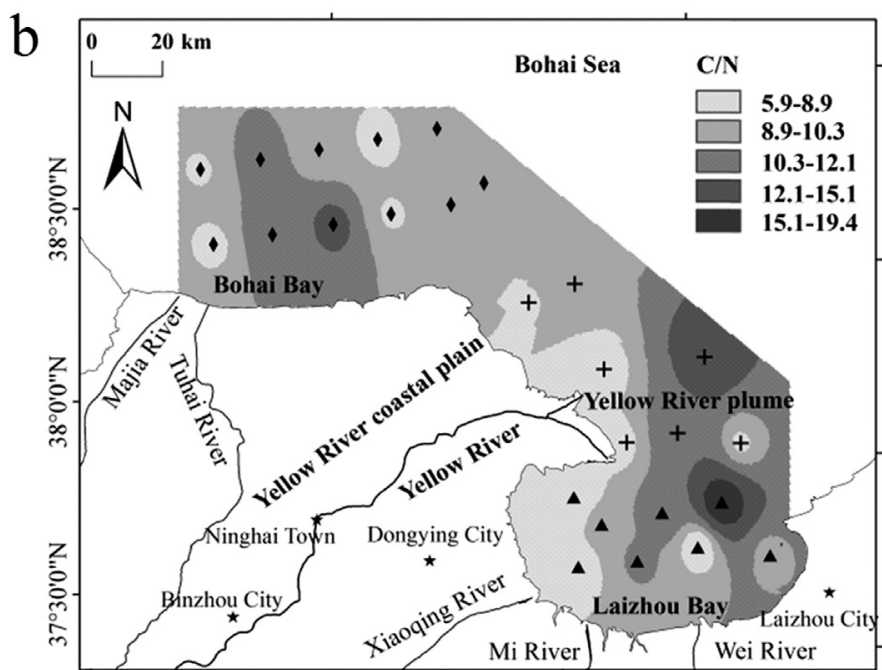

$117^{\circ} 30^{\prime} 0^{\prime \prime} \mathrm{E}$ $119^{\circ} 50^{\prime} 0^{\prime \prime} \mathrm{E}$

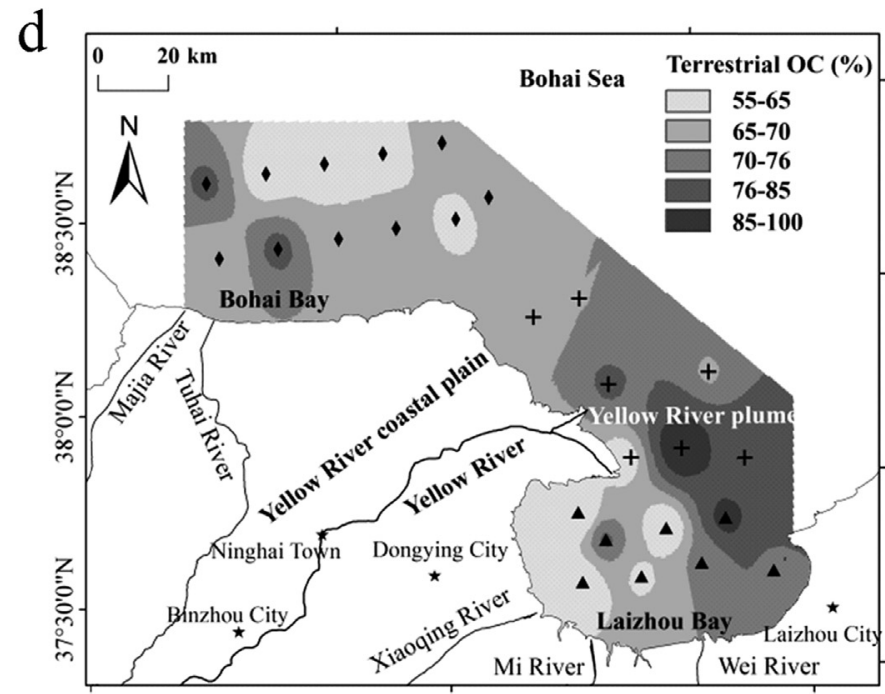

$117^{\circ} 30^{\prime} 0^{\prime \prime} \mathrm{E}$

$118^{\circ} 40^{\prime} 0^{\prime \prime} \mathrm{E}$

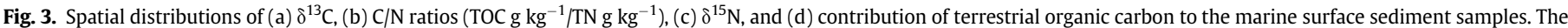

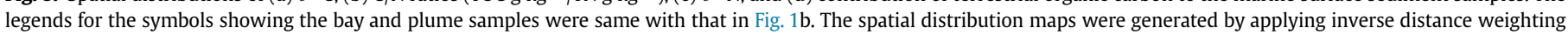
method in Geostatistical Analyst extension of ArcGIS 10.0 (ESRI, Redlands, CA, USA). 
significant depletion in the Yellow River plume $(3.70 \pm 0.75 \%$, $p<0.05)$ and an increasing trend northwest in Bohai Bay $(4.61 \pm 0.48 \%$ o $)$ and southeast in Laizhou Bay $(4.63 \pm 1.14 \%$ ) (Fig. 3c). The $\delta^{15} \mathrm{~N}$ was also correlated significantly with the TN content and the median grain size for all the marine sediment samples ( $r=0.465, p<0.05$ and $r=-0.420, p<0.05$, respectively).

\section{Discussion}

\subsection{Stable isotopic fractionation in the soils from nature to cropping} systems

Soil is a direct sink for organic carbon and the stable isotopic signature of the organic carbon depends greatly on the dominant vegetation. The $C_{3}$ plants have a different $\delta^{13} \mathrm{C}$ value from $C_{4}$ plants (Fig. 4a). The Suaeda, reed and tamarix which are the three dominant plants in the wetlands of the Yellow River coastal plain have an average $\delta^{13} \mathrm{C}$ value of $-27.1 \%$ (Ding et al., 2011), which is within the range of the $\delta^{13} \mathrm{C}$ values for general $C_{3}$ plants. Therefore, the low value of $\delta^{13} \mathrm{C}$ in the wetland soils implies that the organic carbon was mainly sourced from the input of the decomposition of fresh plant litters (Fig. 2a). The maize $\left(C_{4}\right)$-wheat $\left(C_{3}\right)$ and corn/wheatvegetable rotation has been adopted by famers in cereal field and vegetable field. The $\mathrm{C}_{4}$ maize-derived $\mathrm{SOC}_{4}$ in cereal and vegetable fields were from $1.64 \%$ to $21.5 \%$ (average $9.56 \%$ ) and from $12.7 \%$ to

sediment in this study soil in this study river sediment in Laizhou Bay Yellow River sediment river sediment in Bohai Bay marine organism in the YRE marine algae freshwater algae n-alkanes from oils $\mathrm{C}_{4}$ plant in the WYRCP $\mathrm{C}_{3}$ plant in the WYRCP $\mathrm{C}_{4}$ plant $\mathrm{C}_{3}$ plant

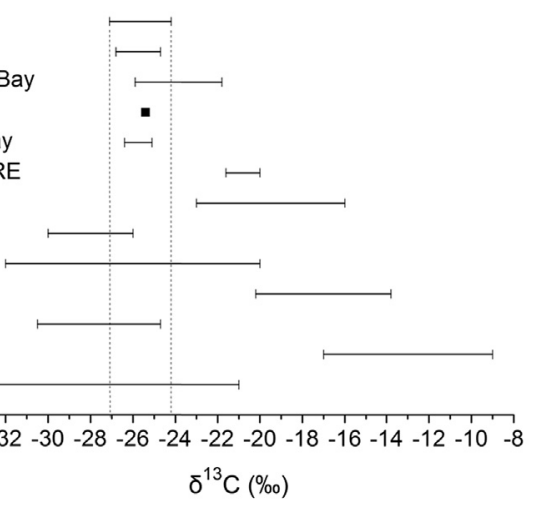

b sediment in this study soil in this study river sediment in Laizhou Bay Yellow River sediment river sediment in southern Bohai Bay wastewater precipitation crude oil in saline environment nitrogen fertilizer in China marine plankton $\mathrm{C}_{4}$ plant in the weland of YRCP $\mathrm{C}_{3}$ plant in the weland of YRCP terrestrial organic matter

$$
\begin{gathered}
-1412-10-8-6-4-2 \quad 0 \quad 2 \quad 4 \quad 6 \quad 8 \quad 101214161820 \\
\delta^{15} N(\%)
\end{gathered}
$$

Fig. 4. Typical (a) $\delta^{13} \mathrm{C}$ and (b) $\delta^{15} \mathrm{~N}$ ranges for organic inputs to coastal environments (data for $C_{3} / C_{4}$ plant, $C_{3}$-dominated freshwater algae, marine algae are compiled from Lamb et al. (2006) and references therein; data for $C_{3} / C_{4}$ plant in the wetland of Yellow River coastal plain (wYRCP), marine plankton, marine organism in the Yellow River plume (YRP), nitrogen fertilizer in China, $n$-alkanes from oils in the Liaohe Plain, crude oil in saline environment in the Liaohe Plain, precipitation in Northern China Plain (for $\mathrm{NH}_{4}-\mathrm{N}$ and $\mathrm{NO}_{3}-\mathrm{N}$ ), wastewater, and river sediments in study area are compiled from Ding et al. (2011), Ruiz-Fernández et al. (2002), Cai (1994), Xiong and Geng (2000), Cao et al. (1991), Chen et al. (2005), McKinney et al. (2001), Zhang et al. (2008) and Wang et al. (2015), respectively).
$18.8 \%$ (average $16.7 \%$ ), respectively (Table 1 ). Therefore, the generally elevated $\delta^{13} \mathrm{C}$ values from cotton to vegetable field could be partly attributed to the increased proportions of $\mathrm{C}_{4}$ carbon in soils, which had much enriched $\delta^{13} \mathrm{C}$ values than $C_{3}$ carbon (Fig. 4a). However, the $C_{3}$ carbon generally remained predominant in the agricultural soil with no more than $22 \% \mathrm{SOC}_{4}$. Meanwhile, land use shift from wetland to cotton field without transfer between $C_{3}$ and $\mathrm{C}_{4}$ plants also resulted in the ${ }^{13} \mathrm{C}$ enrichment in the soils. This was probably because of the preferential stabilization of ${ }^{13} \mathrm{C}$ enriched compounds and the preferential decomposition of ${ }^{13} \mathrm{C}$ depleted compounds during the mineralization and humification processes (Rumpel and Kögel-Knabner, 2011). Therefore, the decomposition of wetland derived carbon can affect carbon accumulation in the agricultural soils.

Soil $\delta^{15} \mathrm{~N}$ values related to the nutrient input, humification and $\mathrm{N}$ transformation as influenced by land use and land cover change (Awiti et al., 2008). Nitrogen fertilizer application was usually below $400 \mathrm{~kg} \mathrm{~N} \mathrm{ha}^{-1}$ year $^{-1}$ in cotton field and was above $500 \mathrm{~kg} \mathrm{~N}$ $\mathrm{ha}^{-1}$ year $^{-1}$ in the double cereals cropping system, while higher than $4000 \mathrm{~kg} \mathrm{~N} \mathrm{ha}^{-1}$ year $^{-1}$ in the greenhouse vegetable cropping of Shandong Provence (Guo et al., 2010; Liu et al., 2010). Therefore, the application of large quantities of nitrogen fertilizer reduced the $\delta^{15} \mathrm{~N}$ value from the cotton field to the vegetable field as shown in Fig. $2 \mathrm{~b}$ due to the contribution of ${ }^{15} \mathrm{~N}$-depleted nitrogen from Chinese nitrogen fertilizer (Cao et al., 1991). In nitrogen-saturated systems, losses of ${ }^{15} \mathrm{~N}$-depleted $\mathrm{N}$ by leaching of nitrate and denitrification leave the remaining available $\mathrm{N}$ enriched in ${ }^{15} \mathrm{~N}$ in soils (Högberg et al., 2011). The long-term application of nitrogen fertilizer could result in ${ }^{15} \mathrm{~N}$ enrichment in farmland compared to wetland.

The results showed that land use shifted from natural system to agricultural system accelerates the transformation of soil organic matter as indicated by the enrichment of heavy stable isotopes in the cropping soils. This implied that the soil organic carbon degraded after the wetland was reclaimed to be farmland (Bai et al., 2013). In the cropping system, the difference of natural abundance of the ${ }^{13} \mathrm{C}$ and ${ }^{15} \mathrm{~N}$ isotopes seemed to be useful in the evaluation of $\mathrm{C}$ and $\mathrm{N}$ dynamics under the condition of soil organic matter decomposition, $\mathrm{C}_{3}-\mathrm{C}_{4}$ plant transformation, fertilization, nitrification and so on during the crop rotation in the Yellow River coastal plain.

\subsection{Source identification of organic carbon in the marine sediment}

The $\delta^{13} \mathrm{C}$ coupled with $\mathrm{C} / \mathrm{N}$ ratios is an effective marker to discriminate the relative proportions of terrigenous and marine sources in the sedimentary organic carbon (Yu et al., 2010; Careddu et al., 2015). The $\delta^{13} \mathrm{C}$ ranges of the marine sediment samples showed a clear separation from the marine biota and $C_{4}$ plants, and an overlap with the soil samples, river sediments, fresh water algae, n-alkanes from oils and $C_{3}$ plants (Fig. 4a). This suggested a significant input of land-derived organic carbon by river transportation from the $\mathrm{C}_{3}$-dominated systems. It should be noted that the rivers around the Bohai Sea annually input large amounts of oils, for example, the Yellow River and Xiaoqing River respectively transported $978 \mathrm{t}$ and $317 \mathrm{t}$ oils to the sea in 2014 (SOA, 2014a), which also contributed to the organic carbon in marine sediments. The low variability of $\delta^{13} \mathrm{C}$ in the marine sediment is due to the mixture and homogenization of the terrestrial soil organic matter, which is similar to that in the Pearl River estuary (Yu et al., 2010). Compared with other river dominated regions, the $\delta^{13} \mathrm{C}$ values of the marine sediment in the Yellow River plume and bay areas were slightly depleted with respect to the Yangtze River estuary ( -24.5 to $-21.2 \%$ ) (Zhang et al., 2007), and comparable to the Pearl River estuary ( -27.0 to $-20.8 \%$ ) (Yu et al., 2010), Colville River estuary 
( -27.1 to $-25.0 \%$ ) (Schreiner et al., 2013) and the Amazon region ( -24 to $-27 \%$ ) (Ramaswamy et al., 2008). The Yellow River sediment flowed primarily southeastward into Laizhou Bay and most of the sediment load was deposited within $35 \mathrm{~km}$ of the river mouth (Qiao et al., 2010). The lowest $\delta^{13} \mathrm{C}$ values around the Yellow River plume area implied the significant contribution of the Yellow River derived terrestrial organic carbon. The west of Laizhou Bay and Bohai Bay usually exhibited a highly eutrophic condition due to the high anthropogenic nutrient loading into coastal systems (for example, the content of dissolved inorganic nitrogen is usually above $28 \mu \mathrm{M}$ (national standard of nitrogen pollution) in an average year and even reach to $70 \mu \mathrm{M}$ in summer), which stimulated preferential growth of certain organisms such as algae (Wu et al., 2013; Liu et al., 2015). The highest $\delta^{13} \mathrm{C}$ values in west of Laizhou Bay and Bohai Bay thus reflected the contribution of anthropogenic nutrient input due to the high $\delta^{13} \mathrm{C}$ values of the marine algae. The suspended sediments were major carriers of organic matter, which was distributed, often in discrete patches, on individual particle surfaces (clay, sand) and also incorporated or adsorbed into mineral structures (pores, laminae) (Blair and Aller, 2012). The decline of the $\delta^{13} \mathrm{C}$ value from the west to the east of the Yellow River plume and Laizhou Bay was agreed with the southward and southeastward transport of the suspended sediments that entrapped by anticlockwise circulation in this area (Qiao et al., 2010).

The distribution patterns of $\mathrm{C} / \mathrm{N}$ ratios in the marine sediments showed a good correlation with $\delta^{13} \mathrm{C}$ (Fig. 3a, b). Algae typically have $\mathrm{C} / \mathrm{N}$ ratios between 5 and 8 , whereas vascular terrestrial plants have the $\mathrm{C} / \mathrm{N}$ ratios typically higher than 15 (Meyers, 1994). The $\mathrm{C} / \mathrm{N}$ ratios ranged from 6 to 15 (mean $9.99 \pm 2.78$ ) in the marine sediment of the study area, indicating a mixture of terrestrial and marine sources. However, the loss of organic matter in sediments as decomposition progresses may complicate the use of $\mathrm{C} / \mathrm{N}$ ratios to identify sources (Lamb et al., 2006). The marine sediment $\mathrm{C} / \mathrm{N}$ ratios were lower than typical terrestrial organic matter but higher than the soils in study area. This might suggest the decomposition of organic matter in marine sediment from the preferential removal of more labile $N$-containing organic matter.

A contour map of the proportion of terrestrial OC in the marine surface sediment was generated by adopting the two end-member mixing model (Fig. 3d). The modeling results showed that, on average, $73.5 \%$ (ranging from $60.4 \%$ to $100 \%$ ) of the sedimentary organic matter was sourced from the terrestrial OC. The proportion of terrestrial sourced OC showed a seaward decline from the north of the Yellow River plume to the south of the Bohai Bay. It also shows an east-west gradient of terrestrial OC from the Yellow River plume to Laizhou Bay. This spatial distribution of the terrestrial $\mathrm{OC}$ is in accordance with the above mentioned suggestion of high primary productivity in the inner bay and dominant contribution of sediment load to sedimentary organic matter in the river plume.

\subsection{Source identification of the nitrogen in the sediment}

The $\delta^{15} \mathrm{~N}$ range of the marine sediment samples showed a clear difference to crude oil and wastewater, however overlapped with the $\delta^{15} \mathrm{~N}$ range of the soil samples, river sediments of the area, precipitation, nitrogen fertilizer, marine plankton, and $C_{3} / C_{4}$ plant (Fig. 4b). Therefore, sources of sedimentary nitrogen in the Bohai Sea were more complicated than the sources of organic carbon, which originated from riverine input, agricultural runoff, atmospheric deposition and autochthonous organics. In the North China Plain, annual bulk deposition of inorganic $\mathrm{N}$ averaged $27 \mathrm{~kg} \mathrm{~N} \mathrm{ha}^{-1}$, which was much higher than the amounts in other regions of China (Zhang et al., 2008). The high amount of deposited nitrogen could be one source to the sedimentary nitrogen in studied sea areas near the plain. The separation of $\delta^{15} \mathrm{~N}$ values among marine sediment samples, crude oil and wastewater was attributed to the mixing sources with very low $\delta^{15} \mathrm{~N}$ values such as nitrogen fertilizer.

Due to the complex sources of nitrogen, the geographical mapping of $\delta^{15} \mathrm{~N}$ could be applied to identify the possible sources and fate of sedimentary nitrogen based on its high spatial variability (Fig. 3c). A relatively enriched $\delta^{15} \mathrm{~N}$ value was observed in sediment samples from the inner Laizhou Bay and the offshore of Bohai Bay. The Laizhou Bay and south of Bohai Bay received a large amount of wastewater from the surrounding rivers, half of which were classified into level V or even worse by the National Environmental Quality Standards of Surface Water (SOA, 2014b). In contrast, The Yellow River plume usually contained lower contaminants loading and the water was better than Class IV (SOA, 2014b). The wastewater was usually characterized by enriched $\delta^{15} \mathrm{~N}$ values which could be above $10 \%$ (McKinney et al., 2001). Therefore, anthropogenic wastewater discharge was an important reason for the occurrence of heavier nitrogen isotope in the inner bay areas, which acted as a sink of anthropogenic nitrogen. Liu et al. (2015) also reported that riverine input contributed significantly to sedimentary nitrogen in the south of Laizhou Bay.

The anthropogenic inputs could also induce the higher marine primary productivity in inner bay as indicated by $\delta^{13} \mathrm{C}$, resulting in the elevated $\delta^{15} \mathrm{~N}$ values because of the relatively enriched $\delta^{15} \mathrm{~N}$ values of marine plankton (Fig. 4b). The lower water exchange rate and higher eutrophication level in Laizhou Bay and Bohai Bay than in the Yellow River plume area has led to an oxygen-deficient condition in inner bay, especially in summer season (Wu et al., 2013). The denitrification process occurred in these oxygendeficient zones could result in elevated $\delta^{15} \mathrm{~N}$ values due to the preferential consumption of light ${ }^{14} \mathrm{~N}$ in comparison to ${ }^{15} \mathrm{~N}$ by denitrifying bacteria (Alkhatib et al., 2012). Similarly, the anthropogenic $N$-fertilizer input in the bay area could also lead to enriched $\delta^{15} \mathrm{~N}$ values through $\mathrm{NH}_{3}$ volatilization and assimilationnitrification-denitrification process (Högberg et al., 2011; Alkhatib et al., 2012). The stable isotopic results indicated a strong contribution of terrestrially-derived organic matter and nutrients to marine sediments although marine process can still have an influence.

\subsection{Fate of the terrigenous organic matter in the coastal zone}

The patterns of carbon and nitrogen stable isotopic fractionation in the soils and sediments in this area mainly fell into six groups based on the description of the dual stable isotopes chart (Fig. 5). The samples from the coastal wetland were classified into group 1 for which the ${ }^{13} \mathrm{C}$ and ${ }^{15} \mathrm{~N}$ tended to be depleted. This group indicated that the fate of carbon and nitrogen was associated with biogeochemical cycling of the wetland (Kiehn et al., 2013). The group 2 contains vegetable soil. The vegetable soil has the highest SOM content and has been heavily and frequently nitrogen fertilized, which made it isotopically different from wetland and cropland soils. The group 3 was associated with the cropland soils (i.e., cotton and cereal soils) developed from the alluvial deposit. The group 4 was linked with the Yellow River sediment. The Yellow River contributes a great amount of runoff and suspended sediments load to both the Yellow River coastal plain and the surrounding seas (Tao et al., 2015). Therefore, the group 4 could also be considered as an intermediate group, which played an important role in the cycling of carbon and nitrogen in the coastal region. The group 5 includes marine sediments in Bohai Bay and Laizhou Bay, and is characterized by the enrichment of ${ }^{15} \mathrm{~N}$ and ${ }^{13} \mathrm{C}$ due to anthropogenic input. The group 6 contains the marine sediment samples from the central Bohai Sea and was different from the other sediments and soils. This group showed a significant 


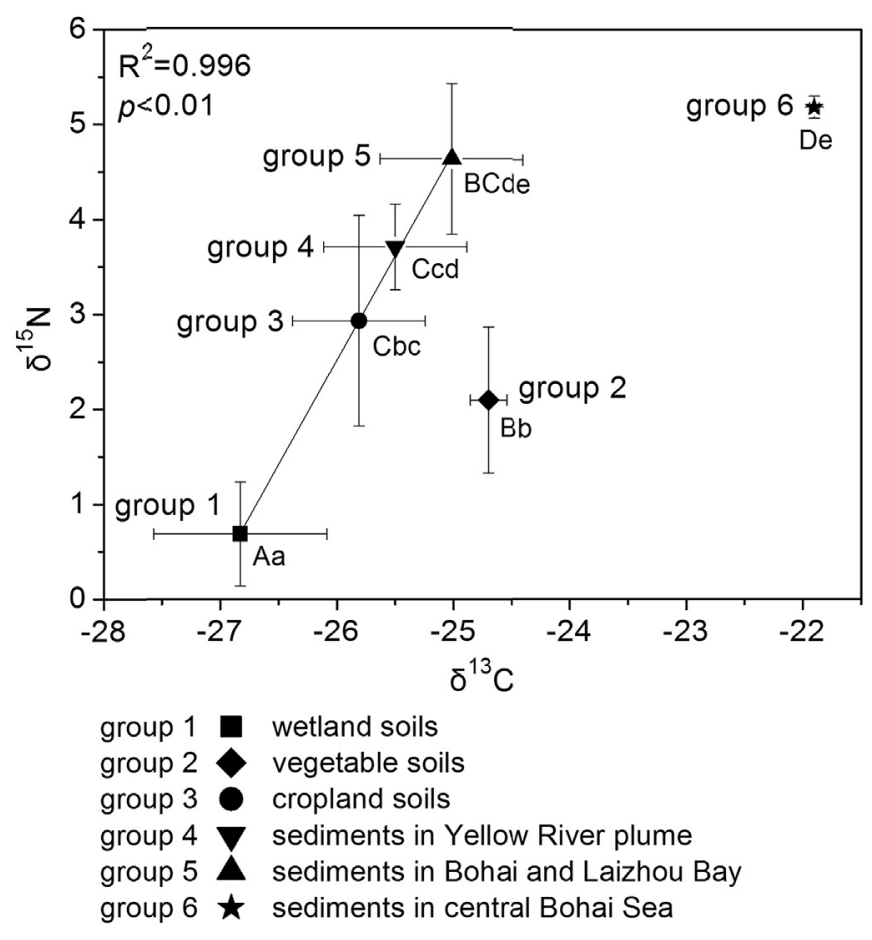

Fig. 5. Biplot of $\delta^{13} \mathrm{C}$ and $\delta^{15} \mathrm{~N}$ in soils and sediments with average deviation shown. Data for marine sediments in central Bohai Sea are from Wang et al. (2015). The sites were located at $119^{\circ} 32^{\prime} 13.6^{\prime \prime} \mathrm{E}, 38^{\circ} 40^{\prime} 0.1^{\prime \prime} \mathrm{N}, \quad 120^{\circ} 0^{\prime} 3.6^{\prime \prime} \mathrm{E}, 39^{\circ} 5^{\prime} 43.1^{\prime \prime} \mathrm{N}$ and $120^{\circ} 28^{\prime} 9.84^{\prime \prime} \mathrm{E}, 39^{\circ} 32^{\prime} 19.0^{\prime \prime} \mathrm{N}$. Linear regression is conducted among group 1 (wetland soils), group 3 (cropland soils), group 4 (marine sediments in Yellow River plume) and group 5 (marine sediments in Bohai and Laizhou Bay). The uppercase letter A, B, C, D and lowercase letter a, b, c, d, e indicate significant difference ( $p<0.05$, Duncan test) of $\delta^{13} \mathrm{C}$ and $\delta^{15} \mathrm{~N}$ values, respectively.

enrichment of the $\delta^{13} \mathrm{C}$ value compared to other groups. Such a large difference in $\delta^{13} \mathrm{C}$ values between group 6 and other groups probably implied that marine primary production has main influence on the cycling of organic matter in the central Bohai Sea, while land-derived materials dominated the cycles in the coastal areas of the Bohai Sea.

The difference of the isotopic fractionation in the soils, plume and marine sediment also reflected the fate of organic matter from the land to the ocean (Raymond and Bauer, 2001; Arzayus and Canuel, 2004; Rumpel and Kögel-Knabner, 2011). As shown in Fig. 5, a linear curve could be fitted for the different isotopic groups, which was from the wetland soils, cropland soils to the marine sediments in the river plume and bay area. The groups 2 and 6 were not included in the linear curve due to the high nitrogen fertilizer and $\mathrm{C}_{4}$-carbon input and the offshore marine production making their isotopically different from other groups. This suggested a linkage between soils and sediments in $C_{3}$-dominant ecosystems of the coastal zone. The transit and temporary storage of organic matter in every depositional environment is accompanied by its alteration and decomposition (Blair and Aller, 2012). The gradually increased trend of isotopic values and $\mathrm{C} / \mathrm{N}$ ratios as shown in the Tables and in the regression line from the wetland soils to the cropland soils then to the marine sediments in the plume and bay areas also supported the decomposition process as discussed above. Besides organic matter decomposition, the Yellow River also exported pre-aged organic matter to the Bohai Sea (Tao et al., 2015). Moreover, the elevated nutrient input from coastal areas of Laizhou Bay and Bohai Bay accelerates the remineralization rates of organic matter (Bianchi and Allison, 2009). Therefore, the $\delta^{13} \mathrm{C}$ and $\delta^{15} \mathrm{~N}$ enrichment from the natural soils to the marine sediments in this area implied the flux of organic matter from a labile organic matter pool in source regions into a more recalcitrant organic matter pool in sink regions.

\section{Conclusions}

This study gives insights into the sources and fate of organic carbon and nitrogen in the soils of the Yellow River coastal plain and its adjacent marine sediments by using $\delta^{13} \mathrm{C}$ and $\delta^{15} \mathrm{~N}$ signature and $\mathrm{C} / \mathrm{N}$ ratio. Land use conversion from the wetland to agriculture in the Yellow River coastal plain led to a reduction in organic carbon and nitrogen contents accompanying with enrichments in $\delta^{13} \mathrm{C}$ and $\delta^{15} \mathrm{~N}$, indicating the release of soil organic carbon and nitrogen derived from the original wetland. In agricultural system, the natural abundance of ${ }^{13} \mathrm{C}$ and ${ }^{15} \mathrm{~N}$ isotopes could effectively evaluate changes in $\mathrm{C}$ and $\mathrm{N}$ dynamics in crop rotation integrating the soil environment. The organic carbon in the marine sediments adjacent to the coastal plain mainly originated from $\mathrm{C}_{3}$-dominated terrestrial systems, with a contribution of terrestrial organic carbon above $60 \%$ (ranging from $60.4 \%$ to $100 \%$ ) in most areas. Riverine nutrients and suspend sediment transport contributes significantly to the cycles of organic carbon and nitrogen in the marine sediments, which was also affected by marine primary productivity and denitrification process. The significantly positive correlation between $\delta^{13} \mathrm{C}$ and $\delta^{15} \mathrm{~N}$ from natural soils to marine sediments indicated that the marine sediments were a potential pool of aged terrestrial organic matter.

\section{Acknowledgments}

This research was supported financially by the National Natural Science Foundation of China (41371313 and 41230858) and WPOS project (No. XDA11020402). We thank Prof. Alice Newton for helpful discussion and proofreading.

\section{Appendix A. Supplementary data}

Supplementary data related to this article can be found at http:// dx.doi.org/10.1016/j.ecss.2016.08.024.

\section{References}

Alkhatib, M., Lehmann, M.F., Del Giorgio, P.A., 2012. The nitrogen isotope effect of benthic remineralization-nitrification-denitrification coupling in an estuarine environment. Biogeosciences 9, 1633-1646.

Arzayus, K.M., Canuel, E.A., 2004. Organic matter degradation in sediments of the York River estuary: effects of biological vs. physical mixing. Geochim. Cosmochim. Ac 69, 455-463.

Awiti, A.O., Walsh, M.G., Kinyamario, J., 2008. Dynamics of topsoil carbon and nitrogen along a tropical forest-cropland chronosequence: evidence from stable isotope analysis and spectroscopy. Agric. Ecosyst. Environ. 127, 265-272.

Bai, J., Xiao, R., Zhang, K., Gao, H., Cui, B., Liu, X., 2013. Soil organic carbon as affected by land use in young and old reclaimed regions of a coastal estuary wetland, China. Soil Use Manage 29, 57-64.

Bauer, J.E., Cai, W.J., Raymond, P.A., Bianchi, T.S., Hopkinson, C.S., Regnier, P.A.G. 2013. The changing carbon cycle of the coastal ocean. Nature 504, 61-70.

Berner, R.A., 1989. Biogeochemical cycles of carbon and sulfur and their effect on atmospheric oxygen over Phanerozoic time. Palaeogeogr. Palaeoecol. 73, 97-122.

Bianchi, T.S., 2011. The role of terrestrially derived organic carbon in the coastal ocean: a changing paradigm and the priming effect. Proc. Natl. Acad. Sci. U. S. A. 109, 19473-19481.

Bianchi, T.S., Allison, M.A., 2009. Large-river delta-front estuaries as natural "recorders" of global environmental change. Proc. Natl. Acad. Sci. U. S. A. 106, 8085-8092.

Bigot, M., Saliot, A., Cui, X., Li, J., 1989. Organic geochemistry of surface sediments from the Huanghe estuary and adjacent Bohai sea (China). Chem. Geol. 75, 339-350.

Blair, N.E., Aller, R.C., 2012. The fate of terrestrial organic carbon in the marine environment. Annu. Rev. Mar. Sci. 4, 401-423.

Cai, D.L., 1994. Geochemical studies on organic carbon isotope of the Huanghe River (Yellow River) estuary. Sci. China Chem. 31, 1001-1015. 
Cai, Y., Guo, L., Wang, X., Aiken, G., 2015. Abundance, stable isotopic composition, and export fluxes of DOC, POC, and DIC from the Lower Mississippi River during 2006-2008. J. Geophys. Res. Biogeosci. http://dx.doi.org/10.1002/ 2015JG003139.

Calder, J.A., Parker, P.L., 1968. Stable carbon isotope ratios as indices of petrochemical pollution of aquatic systems. Environ. Sci. Technol. 2, 535-539.

Cao, Y.C., Sun, G.Q., Xing, G.X., Xu, H., 1991. Nature abundance of $\delta^{15} \mathrm{~N}$ in main Ncontaining chemical fertilizers of China. Pedosphere 1, 377-382.

Careddu, G., Costantini, M.L., Calizza, E., Carlino, P., Bentivoglio, F., Orlandi, L., Rossi, L., 2015. Effects of terrestrial input on macrobenthic food webs of coastal sea are detected by stable isotope analysis in Gaeta Gulf. Estuar. Coast. Shelf S. $154,158-168$

Chen, C.P., Mei, B.W., Cao, Y.C., 2005. Nitrogen isotopic geochemical characteristics of crude oils in several basins of China. Sci. China Earth Sci. 48, 1211-1219.

Cloern, J.E., Canuel, E.A., Harris, D., 2002. Stable carbon and nitrogen isotope composition of aquatic and terrestrial plants of the San Francisco Bay estuarine system. Limnol. Oceanogr. 47, 713-729.

Cook, R.L., Stape, J.L., Binkley, D., 2013. Soil carbon dynamics following reforestation of tropical pastures. Soil Sci. Soc. Am. J. 78, 290-296.

Covaci, A., Harrad, S., Abdallah, M.A.E., Ali, N., Law, R.J., Herzkef, D., de Wit, C.A., 2011. Novel brominated flame retardants: a review of their analysis, environmental fate and behavior. Environ. Int. 37, 532-556.

Da, C.N., Liu, G.J., Yuan, Z.J., 2014. Analysis of HCHs and DDTs in a sediment core from the old Yellow River estuary, China. Ecotox. Environ. Safe 100, 171-177.

de Haas, H., van Weering, T.C.E., de Stigter, H., 2002. Organic carbon in shelf seas: sinks or sources, processes, and products. Cont. Shelf Res. 22, 691-717.

Ding, X.G., Ye, S.Y., Wang, J.S., 2011. Stable carbon and nitrogen isotopes in the Yellow River Delta wetland. Mar. Geol. Front. 27, 66-71 (in Chinese).

Fang, H., Liu, G., Kearney, M., 2005. Georelational analysis of soil type, soil salt content, landform, and land use in the Yellow River Delta, China. Environ. Manage 35, 72-83.

Guo, J.H., Liu, X.J., Zhang, Y., Shen, J.L., Han, W.X., Zhang, W.F., Christie, P., Goulding, K.W.T., Vitousek, P.M., Zhang, F.S., 2010. Significant acidification in major Chinese croplands. Science 327, 1008-1010.

Hedges, J.I., Keil, R.G., 1995. Sedimentary organic matter preservation: an assessment and speculative synthesis. Mar. Chem. 49, 81-115.

Högberg, P., Johannisson, C., Yarwood, S., Callesen, I., Näsholm, T., Myrold, D.D., Högberg, M.N., 2011. Recovery of ectomycorrhiza after 'nitrogen saturation' of a conifer forest. New Phytol. 189, 515-525.

Hu, J., Peng, P.A., Jia, G., Mai, B., Zhang, G., 2006. Distribution and sources of organic carbon, nitrogen and their isotopes in sediments of the subtropical Pearl River estuary and adjacent shelf, Southern China. Mar. Chem. 98, 274-285.

Kiehn, W.M., Mendelssohn, I.A., White, J.R., 2013. Biogeochemical recovery of oligohaline wetland soils experiencing a salinity pulse. Soil Sci. Soc. Am. J. 77, 2205-2215.

Kong, D., Miao, C., Borthwick, A.G., Duan, Q., Liu, H., Sun, Q., Ye, A., Di, Z., Gong, W., 2015. Evolution of the Yellow River Delta and its relationship with runoff and sediment load from 1983 to 2011. J. Hydrol 520, 157-167.

Lamb, A.L., Wilson, G.P., Leng, M.J., 2006. A review of coastal palaeoclimate and relative sea-level reconstructions using $\delta^{13} \mathrm{C}$ and $\mathrm{C} / \mathrm{N}$ ratios in organic material. Earth Sci. Rev. 75, 29-57.

Lehmann, M.F., Bernasconi, S.M., Barbieri, A., McKenzie, J.A., 2002. Preservation of organic matter and alteration of its carbon and nitrogen isotope composition during simulated and in situ early sedimentary diagenesis. Geochim. Cosmochim. Ac 66, 3573-3584.

Li, G.X., Wei, H.L., Han, Y.S., Cheng, Y.J., 1998. Sedimentation in the Yellow River delta, part I: flow and suspended sediment structure in the upper distributary and the estuary. Mar. Geol. 149, 93-111.

Liu, C., Zheng, X., Zhou, Z., Han, S., Wang, Y., Wang, K., Liang, W., Li, M., Chen, D., Yang, Z., 2010. Nitrous oxide and nitric oxide emissions from an irrigated cotton field in Northern China. Plant Soil 332, 123-134.

Liu, D., Li, X., Emeis, K.C., Wang, Y., Richard, P., 2015. Distribution and sources of organic matter in surface sediments of Bohai Sea near the Yellow River Estuary, China. Estuar. Coast. Shelf S 165, 128-136.

McKinney, R.A., Nelson, W.G., Charpentier, M.A., Wigand, C., 2001. Ribbed mussel nitrogen isotope signatures reflect nitrogen sources in coastal salt marshes, Ecol. Appl. 11, 203-214.

Meyers, P.A., 1994. Preservation of elemental and isotopic source identification of sedimentary organic matter. Chem. Geol. 114, 289-302.

Middelburg, J.J., Herman, P.M.J., 2007. Organic matter processing in tidal estuaries. Mar. Chem. 106, 127-147.

Milliman, J.D., Syvitski, J.P.M., 1992. Geomorphic/tectonic control of sediment discharge to the ocean: the importance of small mountainous rivers. J. Geol.
100, 525-544.

Pang, J.Z., Si, S.H., 1979. The estuary changes of the Huanghe. Oceanol. Limnol. Sin. 10, 136-141 (in Chinese).

Qiao, S.Q., Shi, X.F., Zhu, A.M., Liu, Y.G., Bi, N.S., Fang, X.S., Yang, G., 2010. Distribution and transport of suspended sediments off the Yellow River (Huanghe) mouth and the nearby Bohai sea. Estuar. Coast. Shelf S 86, 337-344.

Ramaswamy, V., Gaye, B., Shirodkar, P.V., Rao, P.S., Chivas, A.R., Wheeler, D., Thwin, S., 2008. Distribution and sources of organic carbon, nitrogen and their isotopic signatures in sediments from the Ayeyarwady (Irrawaddy) continental shelf, northern Andaman Sea. Mar. Chem. 111, 137-150.

Raymond, P.A., Bauer, J.E., 2001. Riverine export of aged terrestrial organic matter to the North Atlantic Ocean. Nature 409, 497-500.

Regnier, P., et al., 2013. Anthropogenic perturbation of the carbon fluxes from land to ocean. Nat. Geosci. 6 (8), 597-607.

Ruiz-Fernández, A.C., Hillaire-Marcel, C., Ghaleb, B., Soto-Jiménez, M., PáezOsuna, F., 2002. Recent sedimentary history of anthropogenic impacts on the Culiacan River Estuary, northwestern Mexico: geochemical evidence from organic matter and nutrients. Environ. Pollut. 118, 365-377.

Rumpel, C., Kögel-Knabner, I., 2011. Deep soil organic matter-a key but poorly understood component of terrestrial C cycle. Plant Soil 338, 143-158.

Schreiner, K.M., Bianchi, T.S., Eglinton, T.I., Allison, M.A., Hanna, A.J., 2013. Sources of terrigenous inputs to surface sediments of the Colville River delta and Simpson's Lagoon, Beaufort sea, Alaska. J. Geophys. Res. Biogeosci. 118, 808-824.

Schultz, D., Calder, J.A., 1976. Organic carbon ${ }^{13} \mathrm{C} /{ }^{12} \mathrm{C}$ variations in estuarine sediments. Geochim. Cosmochim. Ac 40, 381-385.

SOA (State Oceanic Administration of China), 2014a. Bulletin of Marine Environmental Quality (in Chinese). http://www.coi.gov.cn/gongbao/nrhuanjing/ nr2014/201503/t20150316_32223.html.

SOA (State Oceanic Administration of China), 2014b. Information of Marine Environment (in Chinese). http://www.soa.gov.cn/zwgk/hyhjxx/201411/t20141106_ 34010.html.

Tang, X., Ellert, B.H., Hao, X.Y., Ma, Y.B., Nakonechny, E., Li, J.M., 2012. Temporal changes in soil organic carbon contents and $\delta^{13} \mathrm{C}$ values under long-term maize-wheat rotation systems with various soil and climate conditions. Geoderma 183-184, 67-73.

Tao, S.Q., Eglinton, T.I., Montluçon, D.B., McIntyre, C., Zhao, M.X., 2015. Pre-aged soil organic carbon as a major component of the Yellow River suspended load: regional significance and global relevance. Earth Planet. Sc. Lett. 414, 77-86.

Wang, Z.Y., Liang, Z.Y., 2000. Dynamic characteristics of the Yellow River mouth. Earth Surf. Proc. Land 25, 765-782.

Wang, R.M., Tang, J.H., Huang, G.P., Chen, Y.J., Tian, C.G. Pan, X.H., Luo, Y.M., Li, J. Zhang, G., 2015. Provenance of organic matter in estuarine and marine surface sediments around the Bohai Sea. Oceanol. Limnol. Sin. 3, 497-507 (in Chinese)

Wu, Z., Yu, Z., Song, X., Yuan, Y., Cao, X., Liang, Y., 2013. Application of an integrated methodology for eutrophication assessment: a case study in the Bohai Sea. Chin. J. Oceanol. Limn. 31, 1064-1078.

Xiong, Y., Geng, A., 2000. Carbon isotopic composition of individual n-alkanes in asphaltene pyrolysates of biodegraded crude oils from the Liaohe Basin, China. Org. Geochem. 31, 1441-1449.

Ye, S., Laws, E.A., Yuknis, N., Ding, X., Yuan, H., Zhao, G., Wang, J., Yu, X., Pei, S. DeLaune, R.D., 2015. Carbon sequestration and soil accretion in coastal wetland communities of the Yellow River delta and Liaohe delta, China. Estuar. Coast 38 1885-1897.

Yu, F.L., Zong, Y.Q., Lloyd, J.M., Huang, G.Q., Leng, M.J., Kendrick, C., Lamb, A.L., Yim, W.W.S., 2010. Bulk organic $\delta^{13} \mathrm{C}$ and $\mathrm{C} / \mathrm{N}$ as indicators for sediment sources in the Pearl River delta and estuary, southern China. Estuar. Coast. Shelf S 87, 618-630.

Zang, Q.Y., 1996. Nearshore Sediment along the Yellow River Delta. Ocean Press, Beijing (in Chinese).

Zhang, J., Huang, W.W., Shi, M., 1990. Huanghe (Yellow River) and its estuary: sediment origin, transport and deposition. J. Hydrol. 120, 203-223.

Zhang, Z., Zhu, M., Wang, Z., Wang, J., 2006. Monitoring and managing pollution load in Bohai Sea, PR China. Ocean. Coast. Manage 49, 706-716.

Zhang, J., Wu, Y., Jennerjahn, T.C., Ittekkot, V., He, Q., 2007. Distribution of organic matter in the Changjiang (Yangtze River) Estuary and their stable carbon and nitrogen isotopic ratios: implications for source discrimination and sedimentary dynamics. Mar. Chem. 106, 111-126.

Zhang, Y., Liu, X.J., Fangmeier, A., Goulding, K.T.W., Zhang, F.S., 2008. Nitrogen inputs and isotopes in precipitation in the North China Plain. Atmos. Environ. 42, $1436-1448$.

Zhang, T.T., Zeng, S.L., Gao, Y., Ouyang, Z.T., Li, B., Fang, C.M., Zhao, B., 2011. Assessing impact of land uses on land salinization in the Yellow River Delta, China using an integrated and spatial statistical model. Land Use Pol. 28, 857-866. 